\title{
Teacher Leadership Perceptions in Turkish Culture: A Qualitative Analysis
}

\author{
Necati Cemaloğlu ${ }^{1}$, Ali Duran ${ }^{2}$ \\ ${ }^{1}$ Prof. Dr., Gazi University, Gazi Education Faculty, Educational Administration Department, Turkey \\ ${ }^{2}$ Teacher, Ministry of National Education, Turkey \\ Correspondence: Necati Cemaloğlu, Prof. Dr., Gazi University, Gazi Education Faculty, Educational Administration \\ Department, Turkey.
}

Received: September 2, 2018

doi:10.11114/jets.v6i11a.3800

\author{
Accepted: October 27, $2018 \quad$ Online Published: November 29, 2018 \\ URL: https://doi.org/10.11114/jets.v6i11a.3800
}

\begin{abstract}
The purpose of this study is to reveal the perceptions of school administrators, teachers, students and parents on characteristics as well as attitudes and behaviours of teacher leaders. Phenomenological research design from qualitative rmethods was employed in this study. The participants were selected from school administrators, teachers, students and parents through maximum diversity sampling method. Data analyses relied on content analyses technique. The findings of the study showed that school administrators and teachers attribute some traits, such as being knowledgeable and leader to teacher leaders, whereas students attach more importance to being reliable, fair and egalitarian. Parents, on the other hand, consider teachers who are friendly and impressive as leaders. It was found in the study that teacher leaders enhance the student learning, become role models and advocate strong collaboration with colleagues. As a result, it can be said that teacher leaders are those having the potential to attract others to follow him / her.
\end{abstract}

Keywords: teacher leader, school improvement, student achievement, equality, justice

\section{Introduction}

Teachers have been considered as employees of school administrators due to an autocratic management style for a long history. From this perspective, it can be argued that teachers, since regarded as employees, have been performing their professions in a silence way without interfering anything outside the classroom because they don't have the authority to question their seniors in school organizations. With a contemporary management philosophy, current school leaders, however, have been in effort to seek for supports of all stakeholders, especially teachers (Gabriel, 2005). Within this context, it can be said that school administrators cannot take the responsibility to take decisions or to make policy on their owns since different stakeholders who have authority, status and power on school administration have a voice in educational processes (Cranston \& Kusanovich, 2016). Unlike conventional leadership theories, distributed leadership emphasizes collaboration and collective initiatives. Frost and Harris (2003) argues that anybody other than the individual at the top of an organization can display leadership behaviours within the organization as it is in the distributed leadership. Harris and Muijs (2005) also stress that leaders are those triggering the change in the organization and don't necessarily need to be positioned at the top of the organization. Instead, anybody in the organization may lead the organization to set off the journey. As a result, school principals who want to reveal strong leadership skills in the organization must consider the power in a different way rather than the traditional perspective and must be willing to share the stage with others (Murphy, 2005).

Scientific studies on school development and change have placed important responsibilities on teachers other than their current roles, such as initiating professional development and change in the classroom (Harris \& Muijs, 2005). At this point, as cited by Lovett (2018), the notion of teacher leadership is the result of other leadership theories and is associated with distributive leadership, pedagogical leadership and learning leadership.

Teacher leadership has been a core element of leadership literature since the 1980s. Teacher leadership, also associated with teacher professionalism, is seen as one of the key components of school development and student achievement (Lovett, 2018). The concept of teacher leadership has become popular in recent years, but it is not considered as a new concept. As a matter of fact, every educator has his colleagues whom they consider to be their leaders, and whose opinions are considered by others, from time to time for consultation and guidance purposes (Danielson, 2006). At the center of initiatives related to teacher leadership lies in the active involvement of teachers in leadership processes 
(York-Barr and Duke, 2004). Teacher leaders are also influential in communication and interaction skills within the organization and in the formation of school cultures. An effective school culture is directly proportional to the qualities of its members and organizational factors (Merideth, 2000). The fundamental characteristic feature of teacher leader is that they are truly informal leaders. They don't take their leadership powers or skills from an official authority or a position in the organization. Instead, this kind of leadership is the result of colleagues, students, parents and other stakeholders' perceptions in the school organizations (Danielson, 2006). Lovett (2018) states that teacher leadership is not a phenomenon only displayed by teachers' own ideas. With respect to this, Harris and Muijs (2005, p.95) put forward some conditions for a teacher to be regarded as leader by others in the organization:

(1) a supportive culture; (2) strong leadership (i.e. support from the headteacher, senior management team and governors); (3) commitment to action enquiry and reflection; (4) innovative forms of professional development; (5) coordinated improvement efforts; (6) high levels of teacher participation and involvement; (7) data richness; (8) collective creativity; (9) shared professional practice; and (10) recognition and reward.

Teacher leadership can be thought of as a situation in which attitudes and behaviors result from the mutual interaction between the members of the organization, rather than the traditional roles attributed to them in the school organizations, and can be displayed by anybody in the organization when needed (Lambert, 2003). Reeves (2008) notes that there will be no decline in the status or power of school principals when they back up teacher leadership in school organizations. Instead, in this way, additional responsibilities would be added to their agenda. Teacher leaders, constantly struggling for teaching something new, tend to take a variety of risks for their job satisfaction and student achievement. They are influential in shaping the school's mission to contribute to school improvement processes (Merideth, 2000). On the other hand, Zepeda, Mayers and Benson (2003) point out the purposes of teachers who want to make a difference in their organizations and intend to be effective on colleagues and students stimulate them to take the responsility of teacher leadership. Harris and Muijs (2005) suggest that the concept of teacher leader is not new. Instead, teachers show leadership behaviors for many years in tasks such as program developing, team memberships, departmental leadership or team leadership, but teachers in these roles serve as representatives of change rather than leaders triggering change. What is more, leadership is not merely regarded as a perception originating in the mind. Just as learning is not just a mental process, leadership requires volunteerism (Merideth, 2000). Analyses of the literature in educational leadership have found that a great many of published sources include different definitions regarding teacher leadership and scholars haven't come to an agreement who is a teacher leader because teacher leadership encompasses a vast majority of attitudes and behaviours in different cultures and organizations (Merideth, 2000). Within this perspective, Katzenmeyer and Moller (2001) describe teacher leaders as those displaying leadership behaviours in and out of the classroom and affecting others in terms of school improvement and student achievement, whereas Harris and Lambert (2003) adopt the belief in which teachers have the opportunity to show leadership skills in various levels within the organization.

Upon closer reading of the studies conducted on teacher leadership, the researchers are typically directed to teacher leaders' traits and behaviours (Ado, 2016; Brosky, 2001; Bryant, 2017; Cherkowski \& Schnellert, 2017; Clayton, 2014; Clayton, Kilbane \& McCarthy, 2017; Cozensa, 2015; Cekuc, 2008; Fairman \& Mackenzie, 2014; Frost \& Durrant, 2003; Katzenmeyer \& Moller, 2001; Kaya, 2016; Khan \& Malik, 2013; Lambert, 2003; Lumpkin, Claxton, \& Wilson, 2014; York-Barr \& Duke, 2004), teacher leadership roles (Al Suwaidi \& Schoepp, 2015; Evans, 1996; Fullan \& Hargreaves, 1996; Ghamrawi, 2013; Katzenmeyer \& Moller, 2001; Kelly, 2011; Little, 2003; Smylie \& Denny, 1990), administrators' roles in teacher leadership (Accardi, 2016; Can, 2010; DeMatthews, 2014; Kolukcu, 2011; Savas, 2016, Smith, 2014), factors affecting teacher leadership (Aslan, 2011; Gonzales, 2001; Kilinc, Cemaloglu ve Savas, 2015; Silva, Gimbert \& Nolan, 2000; Smylie \& Denny, 1990), teacher leaders in school improvement and change (Ankrum, 2016; Fairman \& Mackenzie, 2015; Frost, 2012; Hook, 2006; Muijs \& Harris, 2003, 2006; Ozcetin, 2013; Wa Ho, 2010), teacher leaders' role in student achievement (Camp, 2011; Mosley, Broyles \& Kaufman, 2014), growing teacher leaders (Bradley-Levine, 2011; Coughlan, 2005; Cranston \& Kusanovich, 2015; Duval; 2017; Hunzicker, 2012; Ross, Adams, Bondy, Dana, Dodman \& Swain, 2011), teacher leaders and distributed leadership (Harris, 2003, 2005), teacher leadership and professional development (Lowery-Moore, Latimer \& Villate, 2016), teacher leaders and organizational culture (Ozturk ve Sahin, 2017), teacher leaders and organizational structure (Rutherford, 2006), teacher leaders and action research (Smeetsa $\&$ Ponte, 2009). The work of Kilinc, Cemaloglu and Savas (2015) tells us that occupational professionalism and perceived stress are significant predictors of teacher leadership. York-Barr and Duke (2004) conducted a conceptual analysis of the importance of teacher leadership, how teacher leader is defined, behaviors and characteristics of teacher leaders, conditions affecting teacher leadership, how teacher leaders can be trained and the effects of teacher leadership. When we examine the studies about teacher leadership, it can be seen that the studies on the identity of teacher leaders are relatively much more than any other related themes about teacher leadership. This means that scholars are still in pursuit of the identity of teacher leader and what characteristics and behaviours a teacher leader has. When the related literature was examined, we didn't come across any study evaluating the perceptions of school administrators, teachers, students and parents, who are the 
main stakeholders of educational organizations of teacher leaders all together. This current study is expected to contribute to the existing literature in terms of revealing the characteristics of teacher leader from the perspective of Turkish school administrators, teachers, students and parents. It is also supposed to make contributions in terms of cultural perspective to a universal issue. That is, revealing who do Turks consider as teacher leader may lead stakeholders to encourage support teacher leaders or trigger silent potential teacher leaders in school organizations. What is more, this study is expected to add to teacher training programmes, revealing the traits of teacher leaders in terms of school members. As cited by Clayton (2014), there are still more seats in the leadership arena for those wishing to express their opinions on teacher leadership and leadership in general, as well. Accordingly, the purpose of this study is to reveal the perceptions of school administrators, teachers, students and parents on characteristics as well as attitudes and behaviours of teacher leaders. In line with this aim, an attempt was made to look for the answers for these sub-research questions:

1. How do Turkish school administrators, teachers, students and parents conceptualize the characteristics of teacher leaders?

2. What are their perceptions regarding the attitudes and behaviours of teacher leaders?

\section{Method}

\subsection{Research Design}

This study is a qualitative one which aims to examine or determine a phenomenon as it is. In these kinds of studies, the situations are attempted to examine thoroughly and are tried to describe "what they are" (Tanriogen, 2014). Phenomonology research design was employed in this study as a research design. Phenomonological studies help us to focus on the situations of which we are aware, but don't have detailed information about them (Yildirim ve Simsek, 2005). At this point, it is considered as a suitable research design for this study.

\subsection{Study Group}

The participants were determined through maximum variety sampling technique from the purposeful sampling methods. The aim of this method is to form a small sample and reflect the participants' views at maxium level (Yildirim \& Simsek, 2005). Within this context, a total of 120 participants including 30 school administrators and 30 teachers from primary, secondary and high schools, 30 students from secondary and high schools as well as 30 parents whose students are in primary, secondary and high schools in Amasya province were selected as the participants of the study. The participants were included in the study voluntarily so that they could answer the research questions in a sincere way. Gender, age, educational level, school type were considered in order to provide the variety in terms of participants. Participants were included from primary, secondary and high schools. Primary school students weren't included in the study, due to they may not be able to express their ideas according to the research questions in detail. While determining the participants, managerial and occupational experience for school administrators, branch and occupational experience for teachers, professions for parents were considered so that maximum variety could be achieved. School administrators were selected as principal, vice principal and deputy. 10 elementary, 18 subject matter and 2 vocational teachers were determined for teachers. When it comes to parents' professions, the distributions can be listed as: half of them housewives, soldier, tradesman, retired, worker, technician, officer, preacher. It can be said that maximum variety has been achieved in terms of all participant groups.

Table 1. Demographic distributions of participants

\begin{tabular}{cccccc}
\hline \multirow{3}{*}{ Gender } & & School Administrator & Teacher & Student & Parent \\
\hline \multirow{5}{*}{ Age } & Female & 10 & 17 & 16 & 20 \\
& Male & 20 & 13 & 14 & 10 \\
& 35 and below & 5 & 16 & - & 9 \\
& $36-40$ & 9 & 3 & - & 9 \\
& $41-45$ & 6 & 5 & - & 8 \\
& $46-50$ & 3 & 4 & - & 5 \\
\multirow{5}{*}{ Education Level } & 51 and above & 7 & 2 & - & - \\
& Primary & - & - & - & 1 \\
& Secondary & - & - & - & 2 \\
& High School & - & - & - & 10 \\
& Associate Degree & - & 1 & - & 4 \\
& Undergraduate & 24 & 24 & - & 13 \\
& Masters Degree & 6 & 5 & - & - \\
& PhD Degree & - & 7 & - & - \\
& $1-5$ & 3 & 6 & - & - \\
& $6-10$ & 5 & 4 & - & - \\
& $11-15$ & 5 & 5 & - & - \\
& $16-20$ & 9 & 8 & - & - \\
\hline \multirow{5}{*}{ Occupational Experience } & 21 and above & 8 & & &
\end{tabular}




\subsection{Data Collection Instrument}

Interview technique was employed in order to reveal the perceptions of the participants regarding the research theme. In a study, if the data are self-evident, there are two ways to obtain such data: individual interviews and group interviews. The data collected in this way are based on verbal communication or narrative. The fact that participants are active in the social world and they express their opinion on the topic makes these methods valuable, so the interview can be considered as the most effective and basic method of qualitative data collection method (Ritchie, Lewis, McNaughton \& Ormston, 2014). Data were obtained by using a semi-structured interview form prepared by the researchers after checking the existing literature and composed of two parts. The first part of the interview form consists of demographic information of the participants, while the second part included the questions revealing the participants' perceptions about the research topic. According to Kvale (1996), the researcher can be considered as a traveller setting forth on a journey together with the participant, and in this context, the researcher interprets the narratives and makes sense of them through interview. The interview technique provides data on participants' past experiences, opinions, feelings and direct knowledge of the level of knowledge about the subject, and collects data on these experiences and perceptions of research participants (Patton, 2002). Interviewing is one of the most effective data collection methods in qualitative research, and during the interview, the researcher aims to investigate human experiences on a specific subject (Kvale, 2006). In qualitative studies, internal validity is a condition which is related to whether the researcher can obtain the expected data by means of current instrument or method (Yildirim ve Simsek, 2005).

\subsection{Data Analysis}

In qualitative studies, data are obtained observations, interviews or document analysis techniques and are exposed to some analyses. The raw data are made ready for the analysis in this way, and are displayed in categories, themes and codes (Miles and Huberman, 1994). When the researcher completes the data collection process, descriptive or content analysis is conducted and themes are formed via words and sentences (Spencer, Ritchie and O'Connor, 2003). A content analysis technique was used to analyze the data obtained in this paper. Content analysis is defined as a systematic, repeatable technique in which certain words of a text are summarized by smaller content categories with certain rules-based coding (Buyukozturk, Cakmak, Akgun, Karadeniz \& Demirel, 2012). In this respect, the themes, categories and codes and participant perceptions formed in the context of the related literature are shown in tables. In the process of analyzing the obtained data in this current study, firstly, the interview records were deciphered and analyzed. Various subcategories were created by considering the common points in the answers given for each question. An independent educational science expert was also asked for to create conceptual categories. The resulting themes, categories and codes are calculated according to the form expressed by Miles and Huberman (1994). According to Miles and Huberman' formulate (1994); reliability = opinion union / opinion union + opinion separation formula, the agreement between the researcher and the expert must be over $90 \%$.

In this qualitative research, credibility, transferability, dependability, confirmability terms were used instead of validity and reliability. For the credibility of the study, the researchers paid attention to being objective from the beginning of the research. As for transferability of the study, the necessary details have been provided in the study. To increase the dependability of the study, the agreement was provided in terms of codes and findings. In order to ensure the dependability of the interview form, it was given to two educational science experts. In line with their recommendations, the form was redesigned and was prepared for preliminary interviews. Preliminary interviews were conducted with two participants from each group to determine whether the questions were clear and understandable. Interviews were held at designated times in order to ensure that they were able to express their feelings clearly and comfortably in line with the appointments made by the participants. In order to ensure the credibility of the work, the data were collected only in the environment of one of the researchers and participants so that the participants were not adversely affected during the interview process. The collected data were summarized and approved by the participants. In order to ensure the confirmability of the study, the findings were checked for compatibility with the conceptual framework. As for the confirmability of the study, how the data was obtained have been explained in detail. In this context, it is determined that the result of the calculations is $92 \%$ and it is understood that the obtained themes, categories and codes are reliable. Participants were coded as P1, P2, P3, ... while displaying participants' own sentences. As the participant opinions are given in different headings as school administrator, teacher, student and parent, the letter P coded in each category represents the participant in the relevant category. In other words, the P1 code given under the heading of the school administrator represents the school administrator and the P1 given under the title of the teacher represents the teacher.

\section{Findings}

\section{Perpections on the Characteristics of Teacher Leaders}

\section{School administrators' perceptions on the characteristics of teacher leaders}

When the data were examined, some striking findings were obtained after the coding processes. At this precise point, 
the codes revaled according to the data obtained from school administrators are presented in Table 2.

Table 2. Teacher leader in the perpections of school administrators

\begin{tabular}{|c|c|c|c|c|}
\hline Codes & $\mathrm{n}$ & Codes & $\mathrm{n}$ & Examples of Participants' Own Thoughts \\
\hline Knowledgeable & 16 & Loveable & 4 & "Teacher leader is the person who owns the responsibility and vision, \\
\hline Guide & 15 & Responsible & 4 & who takes the opinions of the group he / she addresses, cares about them, \\
\hline Devoted & 12 & Respected & 4 & creates awareness within the group, motivates the students, well knows \\
\hline Role Model & 11 & Connective & 4 & the group he leads and brings out the best of their potentials". (P3) \\
\hline Motivator & 10 & Persuader & 3 & the one who has develoned teachino skills \\
\hline Principled & 9 & Productive & 3 & $\begin{array}{l}\text { leacher leader is the one who has developed teaching skills and } \\
\text { knowledge and is open for new developments requried by digital age. The }\end{array}$ \\
\hline Leader & 9 & Influential & 3 & teacher who leaves traces on students and never gives up due to \\
\hline Skillful & 8 & Polite & 3 & difficulties in the education system can be called as a teacher leader". \\
\hline Practitioner & 7 & Developer & 2 & $(\mathrm{P} 13)$ \\
\hline Confidential & 7 & Free & 2 & \\
\hline Self-reliant & 7 & Modest & 2 & "Teacher leader is the one who attends formal and informal educational \\
\hline Unique & 7 & Social & 2 & activities willingly and brings colleagues and students in positive \\
\hline Decisive & 6 & Innovative & 2 & attitudes and behaviours". (P24) \\
\hline Consistent & 5 & Total & 167 & $\begin{array}{l}\text { "Teacher who is able to find solutions rather than being the part of the } \\
\text { problem, is able to develop empathy, pays attention to national and } \\
\text { intangible assets and is able to transmit them to the students, informs } \\
\text { people and deserves praise is called as a teacher leader". (P26) }\end{array}$ \\
\hline
\end{tabular}

As shown in Table 2, school administrators mostly regard teacher leaders as knowledgeable $(n=16)$, guide $(n=15)$, devoted $(n=12)$, role model $(n=11)$ and motivator $(n=10)$. In addition, such codes as principled $(n=9)$, leader $(n=$ $9)$, skillful $(n=8)$, practitioner $(n=7)$, confidential $(n=7)$, self-reliant $(n=7)$, unique $(n=7)$ and decisive $(n=6)$ were formed according to the perceptions of school administrators. Other codes formed can be listed as: consistent $(n=5)$, loveable $(n=4)$, responsible $(n=4)$, respected $(n=4)$, connective $(n=4)$, persuader $(n=3)$, productive $(n=3)$, influential $(n=3)$, polite $(n=3)$, developer $(n=2)$, free $(n=2)$, modest $(n=2)$, social $(n=2)$, innovative $(n=2)$. When the codes displayed in Table 2 are evaluated, it can be argued that teacher leaders have extraordinary characteristic features in the perceptions of school administrators. School administrators regard teacher leaders as those who can create the difference in ordinary environments with their professional identities. Additionally, they attach importance some cultural values, including devoted, loveable and persuader. In the perpections of the school administrators, teachers leaders are those who consider teaching as a life style along with a professional occupation.

\section{Teachers' perceptions on the characteristics of teacher leaders}

When the data were examined, some striking findings were obtained after the coding processes. At this precise point, the codes revaled according to the data obtained from teachers are presented in Table 3.

Table 3. Teacher leader in the perpections of teachers

\begin{tabular}{|c|c|c|c|c|}
\hline Codes & $\mathrm{n}$ & Codes & $\mathrm{n}$ & Examples of Participants' Own Thoughts \\
\hline Leader & 19 & Sharer & 6 & "Teacher leader is the person who leads students, colleagues and parents in \\
\hline Knowledgeable & 17 & Unique & 5 & educational and social activities". (P2) \\
\hline Role Model & 16 & Skillful & 4 & $\begin{array}{l}\text { "Teacher leader is the one who pioneers in terms of knowledge and skills and takes } \\
\text { the lead to become role models for others. This kind of leadership may stem from }\end{array}$ \\
\hline Innovative & 10 & Organized & 4 & teachers'own personality or can be learned while performing the occupation, as \\
\hline Confidential & 9 & RiskTaker & 2 & well’’.(P8) \\
\hline Motivator & 8 & Egalitarian & 2 & $\begin{array}{l}\text { "Teacher leader takes the lead for developing colleagues, students as well as } \\
\text { parents rather than transmitting knowledge directly and becomes the pioneer for }\end{array}$ \\
\hline Democratic & 8 & Supervisor & 2 & improvement. Being confidential, unique vision and risk taking are the basic \\
\hline Responsible & 7 & Social & 2 & $\begin{array}{l}\text { characteristics of a teacher leader. A teacher leader minds differences and } \\
\text { embraces all". (P11) }\end{array}$ \\
\hline Active & 7 & Consistent & 2 & "A teacher leader is the teacher who shares his / her knowledge and is able to \\
\hline Authority & 6 & Productive & 2 & realize lots of tasks simultaneously. What is more, being organized, confidential and \\
\hline Total & & & 138 & guide both in the classroom and in the school are the core characteristics". (P16) \\
\hline
\end{tabular}

As shown in Table 3, teachers mostly regard teacher leaders as leader $(n=19)$, knowledgeable $(n=17)$, role model $(n=$ 16), innovative $(n=10)$ and confidential $(n=9)$. In addition, such codes as motivator $(n=8)$, democratic $(n=8)$, responsible $(n=7)$, active $(n=7)$, authority $(n=6)$, sharer $(n=6)$, different $(n=5)$, skillful $(n=4)$ and organized $(n=4)$ 
were formed according to the perceptions of teachers. Other codes formed can be listed as: risk taker $(n=2)$, egalitarian $(n=2)$, supervisor $(n=2)$, social $(n=2)$, consistent $(n=2)$ and productive $(n=2)$. When the codes displayed in Table 3 are evaluated, it can be argued that as it is in the case of school administrators, teacher leaders have extraordinary characteristic features in the perceptions of teachers. Additionally, it can be suggested that teacher leaders have some professional skills as well as personal traits in the perceptions of teachers. Given that teacher leaders contribute a lot to their colleagues, especially in terms of professional development and improving instructing, those codes presented in Table 3 reflect the importance of being a teacher leader.

\section{Students' perceptions on the characteristics of teacher leaders}

When the data were examined, some striking findings were obtained after the coding processes. At this precise point, the codes revaled according to the data obtained from students are presented in Table 4.

Table 4. Teacher leader in the perpections of students

\begin{tabular}{|c|c|c|}
\hline Codes & $\mathrm{n}$ & Examples of Participants' Own Thoughts \\
\hline Confidential & 20 & \\
\hline Fair & 16 & $\begin{array}{l}\text { "Teacher leader is the teacher who doesn 't ignore the injustice and doesn't classify the students } \\
\text { according to certain criterias, such as academic achievements, parents'status. Respect students' }\end{array}$ \\
\hline Egalitarian & 15 & personalities". (P2) \\
\hline Valuing & 15 & \\
\hline Listener & 13 & "Teachers who have an influence on us are our leaders. First of all, our teacher leader doesn't \\
\hline Entertainer & 11 & $\begin{array}{l}\text { make comparisons among students and don't discriminate. Rather, treat everybody equally. Then, } \\
\text { those are considered as leaders by students". (P4) }\end{array}$ \\
\hline Sincere & 8 & \\
\hline Respected & 7 & "A teacher who always talks to us logically is my teacher leader. He / she often exemplifies what he \\
\hline Interested & 5 & / she teaches, never mentions the things he / she doesn't know. Listen to the students until the end. If \\
\hline Authoritarian & 5 & $\begin{array}{l}\text { the students are wrong, he / she justifies his / her ideas. Teacher leader is a person that students } \\
\text { never fear from asking questions." (P5) }\end{array}$ \\
\hline Loveable & 4 & \\
\hline Tolerant & 4 & "A teacher leader is the teacher who behave friendly and talks to the students accordingly. He / she \\
\hline Understanding & 3 & not only teaches about the courses, but also gives advises to the students about the real life. He/she \\
\hline Consistent & 3 & is the teacher with whom we can communicate outside the classroom." (P15) \\
\hline Social & 3 & \\
\hline Sharer & 3 & $\begin{array}{l}\text { "I see teachers who are sincere as my leader. I must be sure about his / her actions and must behave } \\
\text { like our mother or father when necessary. I must be able to trust my teacher leader. I must believe }\end{array}$ \\
\hline Unique & 2 & that his / her ideas, thought and feelings are real and true. I must be able to ask for help whenever I \\
\hline Innovative & 2 & $\begin{array}{l}\text { need. He / she must reflect the person whom I want to be in the future. He / she must be happy and } \\
\text { must make us happy. I cannot consider a teacher whom I cannot trust." (P24) }\end{array}$ \\
\hline Modest & 2 & \\
\hline Total & 141 & \\
\hline
\end{tabular}

As shown in Table 4, students mostly regard teacher leaders as confidential $(n=20)$, fair $(n=16)$, egalitarian $(n=15)$, valuing $(n=15)$, listener $(n=13)$, entertainer $(n=11)$, sincere $(n=8)$ respected $(n=7)$. In addition, such codes as interested $(n=5)$, authoritarian $(n=5)$, loveable $(n=4)$, tolerant $(n=4)$, understanding $(n=3)$, consistent $(n=3)$, social $(n=3)$, sharer $(n=3)$, unique $(n=2)$, innovative $(n=2)$ and modest $(n=2)$ were formed according to the perceptions of students. When the codes displayed in Table 4 are evaluated, it can be argued that students attach more importance to being personality rather than teaching skills. The most important characteristics given importance by students are being confidential, fair and egalitarian. At this point, it can be argued that students want to trust their teachers and then they mind professional skills as teachers.

\section{Parents' perceptions on the characteristics of teacher leaders}

When the data were examined, some striking findings were obtained after the coding processes. At this precise point, the codes revaled according to the data obtained from parents are presented in Table 4. 
Table 5. Teacher leader in the perpections of parents

\begin{tabular}{|c|c|c|c|c|}
\hline Codes & $\mathrm{n}$ & Codes & $\mathrm{n}$ & Examples of Participants' Own Thoughts \\
\hline Loveable & 16 & Innovative & 4 & \multirow{5}{*}{$\begin{array}{l}\text { "Teacher leaders are those who are able to influence students and } \\
\text { make differences about the students' life. They are teachers who can } \\
\text { transform negative behaviours into positive ones." (P2) } \\
\text { "Teachers who are able to bring students in new visions, positive } \\
\text { attitudes and behaviours, motivation for the future and guide } \\
\text { students with their experiences can be defined as teacher leaders". } \\
\text { (P3) }\end{array}$} \\
\hline $\begin{array}{c}\text { Influentia } \\
\text { I }\end{array}$ & 14 & Understanding & 4 & \\
\hline Fair & 9 & $\begin{array}{c}\text { Transformativ } \\
\text { e }\end{array}$ & 4 & \\
\hline $\begin{array}{c}\text { Egalitaria } \\
\mathbf{n}\end{array}$ & 8 & Sympathetic & 4 & \\
\hline Respected & 6 & Social & 4 & \\
\hline $\begin{array}{l}\text { Authorita } \\
\text { rian }\end{array}$ & 6 & Ethical & 3 & \multirow{2}{*}{$\begin{array}{l}\text { "If a teacher displays behaviours consistently both in and out of the } \\
\text { classroom and encourages positive behaviours, then he / she is the } \\
\text { leader." (P17) }\end{array}$} \\
\hline $\begin{array}{c}\text { Role } \\
\text { Model }\end{array}$ & 6 & Tender & 3 & \\
\hline$\underset{t}{\text { Consisten }}$ & 5 & Foreseeing & 2 & \multirow{5}{*}{$\begin{array}{l}\text { "Teacher leaders are those who define objectives, give confidence, } \\
\text { show decisiveness. They are the ones who believe the future and } \\
\text { success. They seek for others' support for the objectives and } \\
\text { collaborate all stakeholders". (P20) }\end{array}$} \\
\hline Sincere & 5 & Empathetic & 2 & \\
\hline Sharer & 5 & $\begin{array}{l}\text { Self-sacrificin } \\
\mathrm{g}\end{array}$ & 2 & \\
\hline Balanced & 5 & Patient & 2 & \\
\hline & & Total & 119 & \\
\hline
\end{tabular}

As shown in Table 5, parents mostly regard teacher leaders as loveable $(n=16)$, influential $(n=14)$, fair $(n=9)$, egalitarian $(n=8)$, respected $(n=6)$, authoritarian $(n=6)$ and role model $(n=6)$. In addition, such codes as consistent $(n=5)$, sincere $(n=5)$, sharer $(n=5)$ and balanced $(n=5)$ were formed according to the perceptions of parents. Other codes formed can be listed as: innovative $(n=4)$, understanding $(n=4)$, transformative $(n=4)$, sympathetic $(n=4)$, social $(n=4)$, ethical $(n=3)$, tender $(n=3)$, foreseeing $(n=2)$, empathetic $(n=2)$, self-sacrificing $(n=2)$ and patient $(n$ $=2$ ). When the codes displayed in Table 6 are evaluated, it can be argued that parents regards teachers who are both tender and authoritarian as teacher leaders. It can also be noted that parents confirm some type of authority in the classroom, especially authority from teachers. This situation can be attributed to cultural structure of the society to some extent that collective cultures often support a little authority.

\section{Perpections on the Attitudes and Behaviours of Teacher Leaders}

In this part of the study, the findings related to perceptions of participants on the attitudes and behaviours of teacher leaders will be presented under different titles.

School administrators' perceptions on the attitudes and behaviours of teacher leaders 
Table 6. Teacher leader's attitudes and behaviours in the perpections of school administrators

\begin{tabular}{|c|c|c|}
\hline Codes & $\mathrm{n}$ & Examples of Participants' Own Thoughts \\
\hline Give condifence & 17 & \\
\hline Affect environment & 12 & \\
\hline Become role model & 12 & $\begin{array}{l}\text { "A teacher leader is the one who behaves kind but firm and sets students } \\
\text { and colleagues into action. He / she also eliminates barriers in front of the }\end{array}$ \\
\hline Behave consistently & 9 & success. He / she takes the necessary measures at the time of crisis. A \\
\hline $\begin{array}{l}\text { Develop himself / } \\
\text { herself }\end{array}$ & 9 & $\begin{array}{l}\text { teacher leader paves the way of the achievements for students." (P1) } \\
\text { "A teacher who makes communication stronger and effective is a leader }\end{array}$ \\
\hline Listen to others & 8 & $\begin{array}{l}\text { one. He / she values the ideas of others and takes risks accordingly. Teacher } \\
\text { leaders are solution oriented people and give confidence people or group }\end{array}$ \\
\hline $\begin{array}{l}\text { Keep up with new } \\
\text { developments }\end{array}$ & 8 & and they are open for development". (P11) \\
\hline $\begin{array}{l}\text { developments } \\
\text { Treat everybody } \\
\text { equally }\end{array}$ & 7 & $\begin{array}{l}\text { "Teacher leaders are the individuals avoiding prejudices and are } \\
\text { negotiators as well as peacemakers. Their words, attitudes and behaviours } \\
\text { are consistent." (P14) }\end{array}$ \\
\hline $\begin{array}{l}\text { Love what he / she } \\
\text { does }\end{array}$ & 7 & $\begin{array}{l}\text { "A teacher leader is the one loved by others, respected and listened in the } \\
\text { environment. He / she is the teacher who harmonises with their } \\
\text { environments or make the environments correspond with him / her." (P17) }\end{array}$ \\
\hline Realize objectives & 7 & ake responsibility in and out of the classroom for \\
\hline Behave ethically & 6 & school improvement and student achievement. Display a strong \\
\hline Eliminate barriers & 6 & psychological structure and they are decisive, self-confident, open-minded \\
\hline Take responsibility & 6 & $\begin{array}{l}\text { team work, able to make a fair decision-making attitude and good role } \\
\text { models." ( }(\mathrm{P} 24)\end{array}$ \\
\hline Collaborate & 5 & "A teacher leader is not the individual causing the problems, rather he / she \\
\hline Take risk & 5 & is the solution itself. They are the ones who can make emphatize with others, \\
\hline Behave kind but firm & 3 & $\begin{array}{l}\text { have high level of national values and can transmit these values to the } \\
\text { students". (P24) }\end{array}$ \\
\hline Search for & 3 & "Teacher who is able to find solutions rather than being the part of the \\
\hline Take prevention & 3 & problem, is able to develop empathy, pays attention to national and \\
\hline Persuade others & 3 & $\begin{array}{l}\text { intangible assets and is able to transmit them to the students, informs } \\
\text { people and deserves praise is called as a teacher leader". (P26) }\end{array}$ \\
\hline Love his / her country & 2 & \\
\hline otal & 138 & \\
\hline
\end{tabular}

As shown in Table 6, school administrators mostly regard teacher leaders' attitudes and behaviours as give confidence $(n=17)$, affect environment $(n=12)$, become role models $(n=12)$, behave consistently $(n=9)$, develop himself / herself $(n=9)$, listen to others $(n=8)$ and keep up with new developments $(n=8)$. In addition, such codes as treat everybody equally $(n=7)$, love what he / she does $(n=7)$, realize objectives $(n=7)$, behave ethically $(n=6)$, eliminate barriers $(n=6)$ and take responsibility $(n=6)$ were formed according to the perceptions of school administrators. Other codes formed can be listed as: collaborate $(n=5)$, take risk $(n=5)$, behave kind but firm $(n=3)$, search for $(n=3)$, take prevention $(n=3)$, persuade others $(n=3)$ ve love his / her country $(n=2)$. When the codes displayed in Table 6 are evaluated, it can be argued that school administrators attach importance to high level of organizational commitment and organizational citizenship behaviours in terms of teacher leadership. At this point, it can be suggested that teacher leaders are expected to be role models to other colleagues with their commitments and citizenship behaviours. 
Teachers' perceptions on the attitudes and behaviours of teacher leaders

Table 7. Teacher leader's attitudes and behaviours in the perpections of teachers

\begin{tabular}{|c|c|c|}
\hline Codes & $\mathrm{n}$ & Examples of Participants' Own Thoughts \\
\hline Develop himself / herself & 14 & "Teacher leaders are the ones who follow the latest developments related \\
\hline Behave fairly & 11 & to their occupations. They come to classroom on time and are \\
\hline Develop empathy & 11 & determinant people who are in pursuit of innovation. They keep up with \\
\hline Behave patiently & 11 & the developments of technological era in which we experience. They try \\
\hline Open for development & 10 & to improve their knowledge and skills and keep their promises. They are \\
\hline Think positive & 10 & diligent individuals who attach importance to being fair. They know their \\
\hline Give confidence & 9 & rlghts." (PI) \\
\hline Follow developments & 9 & "Teacher leaders are teachers who show the full traits of an ideal \\
\hline Become entrepreneur & 8 & teacher and make others feel the prestige of being a teacher and protect \\
\hline Collaborate & 8 & the notability of being a teacher. They are the ones who are comfortable \\
\hline Become role model & 7 & with themselves and have positive feelings towards children. They are \\
\hline Motivate others & 7 & pleased to teach others." (P9) \\
\hline Behave socially & 7 & \\
\hline Build authority & 6 & "Teacher leaders are those who are fond of collaboration with others for \\
\hline Search for & 6 & school improvement and student achievement." (P11) \\
\hline Keep his / her promises & 5 & "A teacher leader is the teacher who knows himself / herself very well. \\
\hline Love what he / she does & 5 & That is, they are aware of their strenghts and weaknesses. In this \\
\hline Realize objectives & 5 & perspective, they always monitor their developments and can regulate \\
\hline Know himself / herself & 4 & their professional skills accordingly. They are tolerant towards \\
\hline Never give up & 4 & objections and trust themselves." (P12) \\
\hline Care diversity & 4 & \\
\hline Know his / her rights & 3 & "Teachers who give importance to the youth and know that the youngs are \\
\hline Take risks & 3 & the future of the country are teacher leaders. They also contribute the \\
\hline Foresee the future & 3 & developments of individuals in a mutli-dimensional way in terms of both \\
\hline Become sharer & 3 & personality and professionally. They are aware of their responsibilities in \\
\hline Love his / her country & 2 & order to lift the country to higher levels in the world arena". (P13) \\
\hline Design curriculum & 2 & \\
\hline $\begin{array}{c}\text { Come to classroom on } \\
\text { time }\end{array}$ & 2 & \\
\hline Toplam & 179 & \\
\hline
\end{tabular}

As shown in Table 7, teachers mostly regard teacher leaders' attitudes and behaviours as develop himself $/$ herself $(n=$ $14)$, behave fairly $(n=11)$, develop empathy $(n=11)$, behave patiently $(n=11)$, open for development $(n=10)$, think positive $(n=10)$. In addition, such codes as give confidence $(n=9)$, follow developments $(n=9)$, become entrepreneur $(n=8)$, collaborate $(n=8)$, become role model $(n=7)$, motivate others $(n=7)$ and behave socially $(n=7)$ were formed according to the perceptions of teachers. Other codes formed can be listed as: build authority $(n=6)$, search for $(n=6)$, keep his / her promises $(n=5)$, love what he / she does $(n=5)$, realize objectives $(n=5)$, know himself / herself $(n=4)$, never give up $(n=4)$, care diverstiy $(n=4)$, know his / her rights $(n=3)$, take risks $(n=3)$, foresee the future $(n=3)$, become sharer $(n=3)$, love his / her country $(n=2)$, design curriculum $(n=2)$ and come to classroom on time $(n=2)$. When the codes displayed in Table 7 are evaluated, it can be argued that teachers attach importance to being fair and develop his / her skills most. Given these codes are considered, teachers well know that both professional skills and personal traits are crucial in teacher leadership. Being fair is given importance in Turkish culture, especially for our teachers. 
Students' perceptions on the attitudes and behaviours of teacher leaders

Table 8. Teacher leader's attitudes and behaviours in the perpections of students

\begin{tabular}{|c|c|c|}
\hline Codes & $\mathrm{n}$ & Examples of Participants' Own Thoughts \\
\hline Behave fairly & 24 & \multirow{5}{*}{$\begin{array}{l}\text { "'To my opinion, teachers who value their students and their } \\
\text { opinions are leaders. A teacher who humiliates students or } \\
\text { colleagues and has an arrogant personality cannot be a } \\
\text { teacher leader, for we, students tend to value teachers who } \\
\text { can understand us and respect us and our values." (P6) }\end{array}$} \\
\hline Treat everybody equally & 23 & \\
\hline Behave consistently & 12 & \\
\hline Make the lessons enjoyable & 10 & \\
\hline Listen to others & 8 & \\
\hline Influence others & 8 & \multirow{3}{*}{$\begin{array}{l}\text { "Teacher leaders are those managing the classroom in a fair } \\
\text { way. At the same time, they are the ones who respect with } \\
\text { colleagues, students and parents". (P20) }\end{array}$} \\
\hline Behave friendly & 8 & \\
\hline Don't compare students & 7 & \\
\hline Don't do an injustice & 6 & \multirow{6}{*}{$\begin{array}{l}\text { "If a teacher is perceived a leader by me or others, then it } \\
\text { can be said that he / she gives confidence and others know } \\
\text { well that they can trust him / her. Teacher leaders are those } \\
\text { who direct the students to the right way rather than revealing } \\
\text { their mistakes. Students know that they are sincere in terms of } \\
\text { their words and actions. They treat students as their own } \\
\text { children. They support us throughout the life." (P28) }\end{array}$} \\
\hline Build authority & 5 & \\
\hline Don't humiliate students & 5 & \\
\hline Behave understandably & 4 & \\
\hline Form vision & 4 & \\
\hline $\begin{array}{c}\text { Know his / her rights } \\
\text { students }\end{array}$ & 2 & \\
\hline Total & 125 & \\
\hline
\end{tabular}

As shown in Table 8, students mostly regard teacher leaders' attitudes and behaviours as behave fairly $(n=24)$, treat everybody equally $(n=23)$, behave consistently $(n=12)$ and make the lessons enjoyable $(n=10)$. In addition, such codes as listen to others $(n=8)$, influence others $(n=8)$, behave friendly $(n=8)$, don't compare students $(n=7)$, don't do an injustice $(n=6)$, build authority $(n=5)$, don't humiliate students $(n=5)$, behave understandably $(n=4)$, form vision $(n=4)$ and know his / her students $(n=2)$ were formed according to the perceptions of students. When the codes displayed in Table 8 are evaluated, it can be argued that students give importance for being fair and ethical issues in terms of teacher leadership. These findings reflect the importance of cultural traits of Turkish society. In other words, Turkish students seek for teachers who are dependable along with professional skills. At this point, it can be suggested that it is not sufficient for a teacher to teach well to be regarded as a teacher leader. Instead, they must have ethical values and display suitables behaviors confirmed by society.

\section{Parents' perceptions on the attitudes and behaviours of teacher leaders}

Table 9. Teacher leader's attitudes and behaviours in the perpections of parents

\begin{tabular}{ccc}
\hline Codes & $\mathrm{n}$ & Examples of Participants' Own Thoughts \\
\hline Influence students & 15 & "Teacher leaders influence others and leave traces. They come \\
Love students & 11 & into prominence with his / her knowledge and skills and have \\
Behave consistently & 10 & strong values". (P4) \\
Treat everybody equally & 10 & \\
Build transformation & 9 & "Teacher leader is the person who is open for developments. He \\
Become role model & 8 & / she finds solutions and is a teacher appreciated by others \\
Build authority & 6 & thanks to futuristic personality." (P5) \\
Behave fairly & 6 & \\
Draw route & 4 & \\
Find solutions & 3 & "Teacher leaders have effective communication with students \\
Behave patiently & 2 & and control the classroom in a fair manner". (P23)
\end{tabular}

As shown in Table 9, teachers mostly regard teacher leaders' attitudes and behaviours as influence students $(n=15)$, love students $(n=11)$, behave consistently $(n=10)$, treat everybody equally $(n=10)$ and build transformation $(n=9)$. In addition, such codes as become role model $(n=8)$, build authority $(n=6)$, behave fairly $(n=6)$, draw route $(n=4)$, find solutions $(n=3)$ and behave patiently $(n=2)$ were formed according to the perceptions of parents. When the codes 
displayed in Table 9 are evaluated, it can be argued that being influential on students and loving them are the most important attitudes and behaviours shown by teacher leaders according to the perceptions of parents. Parents consider those who display affection to their students as teacher leaders. At this point, it can be noted that teaching occupation is not just a professional occupation in Turkey, but a respected one by the all stakeholders in society.

\section{Results, Discussion and Recommendations}

This study has evaluated the perceptions of school administrators, teachers, students and parents on teacher leaders' characteristics, attitudes and behaviours. Following the thematic analysis of the data from the qualitative interviews with participants on teacher leadership, we identified some key concepts that capture the participants when reframing teacher leaders. Findings highlighted that participants' perceptions are in the same line with minor differences. That is, school principals and teachers attribute some traits to teacher leaders, such as being knowledgeable and leader, whereas students give more importance to being reliable, fair and egalitarian. On the other hand, parents embrace teachers who are friendly and impressive as teacher leaders. In this present study, teacher leaders are considered as leaders. In a study conducted by Kaya (2016), teacher leaders are referred as "lighthouse" due to the fact that teacher leaders help others to find their ways. Brosky (2011) found that teacher leaders are regarded as influencers and give confidence to others. Cekuc (2008) also obtained the findings such attributes as honest, hardworking, smiling, helpful, sharer, fair and egalitarian. The findings indicated that school administrators regard teacher leaders as connective, open for development, persuader, principled, decisive, polite, free, self-reliant, devoted, respected, loveable and practitioner, while teachers attribute some different traits such as active, democratic, supervisor, organized and risk taker. When these findings are compared, it can be argued that teachers also refer the traits related to teaching as well as other general characteristics of teacher leaders. Students, on the other hand, refer these traits, including enjoyable, listener, tolerant and interested, whereas parents also see teacher leaders are individuals who are ethical, transformative, empathetic, foreseeable, self-sacrificing, balanced, patient and sympathetic. In line with this, Lumpkin, Claxton ve Wilson (2014) highlight that schools need teacher leaders in order for an effective collaboration to achieve school improvement and student achievement. The work of Ado (2016) tells us that teacher leaders contribute to collaborative culture in teaching environments, while the article by Cherkowski ve Schnellert (2017) shows that teacher leaders act in collaboration with colleagues for organizational change and improvement in collective trust. As indicated by Cosenza (2015), teacher leaders are willing to cooperate with colleagues for student learning by sharing knowledge, supporting in difficult times, becoming role model, acting without hesitation and defining mutual objectives.

The second theme of this study focused on the attitudes and behaviours displayed by teacher leaders. School administrators consider that teacher leaders behave ethically, eliminate barriers, persuade, take responsibility, take measures and behave kind but firm, while teachers perceive that teacher leaders come to classroom on time, predict the future, know themselves, design curriculums, never give up, think positively, behave socially and follow the latest trends in teaching. As mentioned above, it can be argued that teachers focus on the attitudes and behaviours as regards the teaching itself along with personal characteristics more than school administrators. This difference may stem from that teachers can be referred as typically those making war in the battle front, so it wouldn't be surprising that they mostly concentrate on attitudes and behaviours related to teaching tasks in the classroom. Students, on the other hand, attribute these attitudes and behaviours, including being considerate, behaving friendly, making the lessons enjoyable, not doing injustice, not comparing students, knowing students, not humiliating students and making students have vision, whereas parents consider that teacher leaders are those finding solutions to the problems, provide transformation, affect students, love students and guide them. In a study conducted by Khan and Malik (2013), they found that teacher leaders are really effective in increasing student achievement and transforming the school and its environment. As Lambert (2003) reminds us, teacher leaders insert their colleagues in a proffesional school culture. The article by Lowery-Moore, Latimer and Villate (2016) shows that teacher leaders prefer leading in the classroom and becoming "change agents" as experienced teachers rather than taking responsibility in managerial issues outside the classroom. The works of Cherkowski and Schnellert (2017) and Fairman and Mackenzie (2014) tell us that teacher leaders adopt an attitude focusing on innovation and improvement. With a similar finding, Bryant (2017) puts forward that teacher leaders act from the heart. It was also stated by Lowery-Moore, Latimer and Villate (2016) that teacher leaders attach importance to diversity in the classroom and school and contribute student achievement and school improvement, taking into consideration multiculturalism. Clayton, Kilbane ve McCarthy (2017) argues that teacher leaders trust students on learning and believe that students give efforts to learn till the end. Can (2010) suggests that instructional time is used effectively by teacher leaders.

This study offers some theoretical contributions. First of all, the findings shed light on cultural perceptions related to teacher leadership. The findings show that teaching has also some cultural aspects and teachers are evaluated within this perspective. In addition, the study highlights that teacher leaders are those creating awareness and differences in their school organizations and add a lot to school culture and climate positively. Secondly, each administrator in educational 
settings can be suggested that they must reveal leadership skills of teachers and include them in improving schools as well as increasing student achievement. The findings of this study has also several practical implications. The results of this article offers a detailed framework attitudes and behaviours related to teacher leadership. The findings may guide teacher trainers in universities and they may give effort to reveal and improve leadership skills of prospective teachers. The present work may be particularly important since it provides some results shedding light on cultural issues with regard to teacher leadership. That is, Turkish school administrators, teachers, students and parents attach more importance to become sincere, dependable, fair, egalitarian and tolerant. As Pehlivan (2017) reminds us, Turkish society has certain merits, such as good-bad, reward-sin in accordance with its social structure, national values and religious beliefs. Within this context, the participants may have focused on personal characteristisc as well as professional knowledge and skills of teacher leaders from these perspectives. That is, it can argued that it is not just enough to teach well an develop professional skills to be considered as a teacher leaders, but is necessary to have valued personal traits appreciated in society.

We outline some recommendations for practitioners, policy makers and researchers in this section of the study. For practitioners, teachers' leadership skills must be revealed and developed. Schools must be supported in line with this purpose. That is, schools must be organized such a way that teachers are able to feel that they are important part of team and must take responsibility both in and out of the classroom, not just in teaching but other issues, as well. For policy makers, it can be suggested that school organizations must be redesigned in terms of both structure and culture so that all stakeholders can contribute to school improvement and student achievement. When it comes to researchers, a new research path would be to evaluate how teacher leaders pursue their characteristics, attitudes and behaviours. Studies on teacher leaders' motivations would also be useful to go more deeply into the notion of teacher leadership. Finally, we regard it a limitation of this research that we have paid little attention to factors such as socio-economic level, school cultures and achievements of the participants. These can also be explored in greater detail to understand teacher leadership in detail. In conclusion, this study is believed to make a valuable contribution to the existing literature of leadership in terms of dealing the issue in a cultural perspective.

\section{References}

Accardi, I. (2016). The role of system leaders in promoting teacher leadership in small schools (Unpublished Doctoral Dissertation). The Sage Colleges, USA.

Ado, K. (2016). From Pre-Service to Teacher Leader: The Early Development of Teacher Leaders. Issues in Teacher Education, 3-21.

Al Suwaidi, F., \& Schoepp, K. (2015). Knowledge and promotion of teacher leadership: An Abu Dhabi exploration. Near and Middle Eastern Journal of Research in Education, 1, 1-20. https://doi.org/10.5339/nmejre.2015.1

Ankrum, R. J. (2016). Utilizing teacher leadership as a catalyst for change in schools. Journal of Educational Issues, 2(1), 151-165. https://doi.org/10.5296/jei.v2i1.9154

Aslan, M. (2011). Öğretmen liderliği davranışları ve sınıf iklimi: öğretmen ve ögrrenci görüşleri bağlamında bir araştırma (Yayımlanmamış Yüksek Lisans Tezi). Osmangazi Üniversitesi, Eskişehir, Türkiye.

Bradley-Levine, J. (2016). Demands for school leaders. International Journal of Teacher Leadership, 7(2), 1-17.

Brosky, D. (2011). Micropolitics in the school: teacher leaders' use of political skill and influence tactics. The International Journal of Educational Leadership Preparation, 6(1), 1-11.

Bryant, R. (2017). Teacher leader behaviors: a quantitative study of a teacher leadership development academy and teacher leaders' five practices of exemplary leadership behaviors (Unpublished Doctoral Dissertation). LaFetra College of Education, USA.

Buyukozturk, S., Cakmak, E. K., Akgun, O. E., Karadeniz, S., \& Demirel, F. (2012). Bilimsel Araştırma Yöntemleri. Ankara: Pegem Akademi

Camp, M. D. (2011). The power of teacher-student relationships in determining student success (Unpublished Doctoral Dissertation). University of Kansas, Missouri, USA.

Can, N. (2009). Öğretmenlerin sınıfta ve okulda liderlik davranışları. Gaziantep Üniversitesi Sosyal Bilimler Dergisi, 8(2), 385-399.

Can, N. (2010). Öğretmen Liderliğinde Müdürlerin Etkisi. Dumlupınar Üniversitesi Sosyal Bilimler Dergisi, 27, 57-66.

Cekuc, S. (2008). Lider öğretmen yeterliliklerinin incelenmesi üzerine empirik bir araştırma (Yayımlanmamış Yüksek Lisans Tezi). Marmara Üniversitesi, İstanbul, Türkiye.

Cherkowski, S., \& Schnellert, L. (2017). Exploring teacher leadership in a rural, secondary school: reciprocal learning 
teams as a catalyst for emergent leadership. International Journal of Teacher Leadership, 8(1), 6-25.

Clayton, C., Kilbane, J., \& McCarthy, M. R. (2017). Growing into inquiry: stories of high school teachers using inquiry for themselves and their students. Journal of Inquiry \& Action in Education, 8(2),1-20.

Clayton, J. K. (2014). The leadership lens: perspectives on leadership from school district personnel and university faculty. International Journal of Educational Leadership Preparation, 9(1), 1-17.

Cosenza, M. N. (2015). Defining teacher leadership affirming the teacher leader model standards. Issues in Teacher Education, 24(2), 79-99.

Coughlan, M. (2005). Teacher leadership - connecting learning to practice (Unpublished Doctoral Dissertation). Saint Mary's College of California, USA.

Cranston, J., \& Kusanovich, K. (2015). Learning to lead against the grain dramatizing the emotional toll of teacher leadership. Issues in Teacher Education, 24(2), 63-78.

Cranston, J., \& Kusanovich, K. (2016). Ethnotheatre and creative methods for teacher leadership. Cham, Switzerland: Palgrave Macmillan. https://doi.org/10.1007/978-3-319-39844-0

Danielson, C. (2006). Teacher leadership that strengthens professional practice. Alexandria, VA: Association for Supervision and Curriculum Development.

DeMatthews, D. (2014). Principal and teacher collaboration: an exploration of distributed leadership in professional learning communities. International Journal of Educational Leadership and Management, 2(2), 176-206. https://doi.org 10.4471/ijelm.2014.16

Duval, J. P. (2017). Teacher leadership in the context of international schools: The key attributes and development of teacher leaders (Unpublished Doctoral Dissertation). Lehigh University, USA.

Evans, R. (1996). The human side of school change. San Francisco: Jossey-Bass.

Fairman, J. C., \& Mackenzie, S. V. (2015). How teacher leaders influence others and understand their leadership. International Journal of Leadership in Education: Theory and Practice, 18(1), 61-87, https://doi.org/10.1080/13603124.2014.904002

Fairman, J. C., \& Mackenzie, S. V. (2014). How teacher leaders influence others and understand their leadership. International Journal of Leadership in Education: Theory and Practice. https://doi.org/10.1080/13603124.2014.904002

Frost, D. (2012). From professional development to system change: teacher leadership and innovation. Professional Development in Education, 38(2), 205-227. https://doi.org/10.1080/19415257.2012.657861

Frost, D., \& Durrant, J. (2003). Teacher leadership: rationale, strategy and impact. School Leadership \& Management: Formerly School Organisation, 23(2), 173-186. https://doi.org/10.1080/1363243032000091940

Frost, D., \& Harris, A. (2003). Teacher leadership: towards a research agenda. Cambridge Journal of Education, 33(3), 479-498. https://doi.org/10.1080/0305764032000122078

Fullan, M., \& Hargreaves, A. (1996). What's worth fighting for in your school (2nd ed.). New York: Teachers College Press.

Gabriel, J. G. (2005). How to thrive as a teacher leader. USA: ASCD.

Ghamrawi, N. (2013). In Principle, It is not only the principal! Teacher leadership architecture in schools. International Education Studies, 6(2), 148-159. https://doi.org/10.5539/ies.v6n2p148

Gonzales, L. D. (2001). Sustainability of teacher leadership beyond the boundariesof an enabling school culture (Unpublished Doctoral Dissertation). University of Florida, USA.

Harris, A. (2003). Teacher leadership as distributed leadership: heresy, fantasy or possibility?. School Leadership \& Management: Formerly School Organisation, 23(3), 313-324. https://doi.org/10.1080/1363243032000112801

Harris, A. (2005). Teacher leadership: more than just a feel-good factor?. Leadership and Policy in Schools, 4(3), 201-219. https://doi.org/10.1080/15700760500244777

Harris, A., \& Lambert, L. (2003) Building Leadership Capacity for School Improvement. Buckingham: Open University Press.

Harris, A., \& Muijs, D. (2005). Improving schools through teacher leadership. Philadelphia: Open University.

Harris, A., \& Mujis, D. (2005). Improving schools through teacher leadership. London: Open University Press. 
Hook, D. P. (2006). The impact of teacher leadership on school effectiveness in selected exemplary secondary schools (Unpublished Doctoral Dissertation). Texas A\&M University, USA.

Hunzicker, J. (2012). Professional development and job-embedded collaboration: how teachers learn to exercise leadership. Professional Development in Education, 38(2), 267-289. https://doi.org/10.1080/19415257.2012.657870

Katzenmeyer, M., \& Moller, G. (2001). Awakening the sleeping giant: Helping teachers develop as leaders. Thousand Oaks, Calif: Corwin Press.

Kaya, B. (2016). Öğretmenlerin öğretmen liderliği yeterlikleri (Yayımlanmamış Yüksek Lisans Tezi). Yüzüncü Yıl Üniversitesi, Van, Türkiye.

Kelly, J. (2011). Teacher's and teacher leaders' perceptions of the formal role of teacher leadership (Unpublished Doctoral Dissertation). Georgia State University, Georgia.

Khan, S., \& Malik, S. K. (2013). Is teacher leadership a fantasy or reality? A Review. Journal of Educational and Instructional Studies, 3(3), 66-72.

Kilinç, A. C., Cemaloglu, N., \& Savas, G. (2015). The relationship between teacher leadership, teacher professionalism, and perceived stress. Eurasian Journal of Educational Research, 58, 1-26. https://doi.org/10.14689/ejer.2015.58.5

Kolukcu, D. (2011). Illköğretim okulu öğretmenlerinin öğretmen liderliğini gösteren davranışlarının gereklilik ve sergilenme derecesine ilişkin görüşleri (Yayımlanmamış Yüksek Lisans Tezi). Başkent Üniversitesi, Ankara, Türkiye.

Kvale, S. (1996). Interviews: An Introduction to Qualitative Research Interviewing. Thousand Oaks: Sage Publications.

Kvale, S. (2006). Dominance Through Interviews and Dialogues. Qualitative Inquiry, 12(3): 480-500. https://doi.org/10.1177/1077800406286235

Lambert, L. (2003). Leadership redefined: an evocative context for teacher leadership. School Leadership \& Management: Formerly School Organisation, 23(4), 421-430. https://doi.org/10.1080/1363243032000150953

Little, J. W. (2003). Constructions of teacher leadership in three periods of policy and reform activism. School Leadership and Management, 23(4), 401-419. https://doi.org/10.1080/1363243032000150944

Lovett, S. (2018). Advocacy for teacher leadership: opportunity, preparation, support, and pathways. New Zealand: Springer. https://doi.org/10.1007/978-3-319-74430-8

Lowery-Moore, H., Latimer, R. M., \& Villate, V. M. (2016). The essence of teacher leadership: A phenomenological inquiry of professional growth. International Journal of Teacher Leadership, 7(1), 1-16.

Lumpkin, A., Claxton, H., \& Wilson, A. (2014). Key characteristics of teacher leaders in schools. Administrative Issues Journal: Connecting Education, Practice and Research, 4(2), 59-67. https://doi.org/10.5929/2014.4.2.8

Merideth, E. M. (2000). Leadership strategies for teachers. Australia: Hawker Brownlow.

Miles, M. B., \& Huberman, A. M. (1994) Qualitative Data Analysis: An Expanded Sourcebook. Thousand Oaks: Sage Publications.

Mosley, C., Broyles, T., \& Kaufman, E. (2014). Leader-member exchange, cognitive style, and student achievement. Journal of Leadership Education, 13(13), 50-69. https://doi.org/10.12806/V13/I3/R4

Muijs, D., \& Harris, A. (2003). Teacher Leadership-Improvement through empowerment?. Educational Management \& Administration, 31(4), 437-448. https://doi.org/10.1177/0263211X030314007

Muijs, D., \& Harris, A. (2006). Teacher led school improvement: Teacher leadership in the UK. Teaching and Teacher Education, 22(8),961-972. https://doi.org/10.1016/j.tate.2006.04.010

Murphy, J. (2005). Connecting teacher leadership and school improvement. California: Corwin Press.

Ozcetin, S. (2013). Öğretmen liderliğinin okulun liderlik kapasitesinin gelişimine etkisi: bir durum çalışması (Yayımlanmamış Yüksek Lisans Tezi). Akdeniz Üniversitesi, Antalya, Türkiye.

Ozturk, N., \& Sahin, S. (2017). Eğitim örgütlerinde örgüt kültürü ve öğretmen liderliği: lider-üye etkileşiminin aracılık rolü. İlköğretim Online, 16(4), 1451-1468. https://doi.org/10.17051/ilkonline.2017.342967

Patton, M. (2002). Qualitative Research and Evaluation Methods. Thousand Oaks, CA: Sage

Pehlivan, B. M. (2017). Kültür, Kolektif Bilindışı ve Semboller: Miyazaki ve 'Ruhların Kaçışı’ Üzerine Bir İnceleme. Erciyes Illetişim Dergisi, 5(1), 362-378. https://doi.org/10.17680/erciyesakademia.291905 
Reeves, D. B. (2008). Reframing teacher leadership to improve your school. USA: Association for Supervision and Curriculum Development.

Ritchie, J., Lewis, J., McNaughton, N. C., \& Ormston, R. (2014). Qualitative research practice: A guide for social science students and researchers. Thousand Oaks: Sage Publications.

Ross, D., Adams, A., Bondy, E., Dana, N., Dodman, S., \& Swain, C. (2011). Preparing teacher leaders: Perceptions of the impact of a cohort-based, job embedded, blended teacher leadership program. Teaching and Teacher Education, 27, 1213-1222. https://doi.org/10.1016/j.tate.2011.06.005

Rutherford, C. (2006). Teacher leadership and organizational structure: The implications of restructured leadership in an Edison school. Journal Educational Change, 7, 59-76. https://doi.org/10.1007/s10833-006-0013-4

Savas, G. (2016). Okul müdürlerinin destekleyici davranışları ile ögretmen liderliği arasındaki ilişski ve bazı değiş̧kenlere göre incelenmesi (Yayımlanmamış Yüksek Lisans Tezi). Gazi Üniversitesi, Ankara, Türkiye.

Silva, D. Y., Gimbert, B., \& Nolan, J. (2000). Sliding the doors: locking and unlocking possibilities for teacher leadership. Teachers College Record, 102(4), 779-804. https://doi.org/10.1111/0161-4681.00077

Smeetsa, K., \& Ponte, P. (2009). Action research and teacher leadership. Professional Development in Education, 35(2), 175-193. https://doi.org/10.1080/13674580802102102

Smith, D. (2014). A Case Study of School District Administrators' Perceptions of Teacher Leadership in One Northwest Missouri School District (Unpublished Doctoral Dissertation). The University of Missouri-Columbia, USA.

Smylie, M. A., \& Denny, J. W. (1990). Teacher leadership: tensions and ambiquities in organizational perspective. Educational Administration Quarterly, 26(3), 235-259. https://doi.org/10.1177/0013161X90026003003

Spencer, L, Ritchie, J., \& O'Connor, W. (2003). Analysis: Practices, Principles and Processes. In: Ritchie J and Lewis J (eds) Qualitative Research Practice. London: SAGE, pp. 199-218.

Tanrıgen, A. (2014). Bilimsel Araştırma Yöntemleri. Ankara: Anı.

Wa Ho, D. C. (2010). Leadership for school improvement: exploring factors and practices in the process of curriculum Change, Early Education \& Development, 21(2), 263-284. https://doi.org/10.1080/10409280903582835

Yildirim, A., \& Simsek, H. (2005). Sosyal Bilimlerde Nitel Araştırma Yöntemleri. Ankara: Seçkin Yayıncılık.

York-Barr, J., \& Duke, K. (2004). What do we know about teacher leadership? findings from two decades of scholarship. Review of Educational Research, 74(3), 255-316. https://doi.org/10.3102/00346543074003255

Zepeda, S. J., Mayers, R. S., \& Benson, B. N. (2003). The call to teacher leadership. New York: Routledge.

\section{Copyrights}

Copyright for this article is retained by the author(s), with first publication rights granted to the journal.

This is an open-access article distributed under the terms and conditions of the Creative Commons Attribution license which permits unrestricted use, distribution, and reproduction in any medium, provided the original work is properly cited. 